\title{
UDINE RADIOCARBON LABORATORY DATE LIST I
}

\author{
VALERIO BARBINA, FRANCO CALLIGARIS, \\ ADRIANO DEL FABBRO, ALESSANDRO TURELLO, \\ and PIERO CIUTI*
}

Centro di Ricerca Applicata e Documentazione Viale Leonardo da Vinci 16, 33100, Udine, Italy

\section{INTRODUCTION}

The radiocarbon laboratory of the Center of Applied Research and Documentation of Udine (CRAD), became operative early in 1977 and uses a benzene liquid scintillation counting method. Benzene is prepared as outlined by Legers and Tamers (1963), Noakes, Kim, and Akers (1967), Belluomini et al (1978). The procedure of chemical synthesis is detailed in CRAD (1977).

The main features of the physical detection system are described by Calligaris and Ciuti (1978) and by Barbina, Calligaris, and Ciuti (1979) and here. Counting vials are low potassium glass cylinders of $5 \mathrm{~cm}^{3}$ volume. An NE 216 liquid scintillator is used, with typical mixing ratio of $3.5 \mathrm{~cm}^{3}$ of benzene in $1.0 \mathrm{~cm}^{3}$ of scintillator. Radiocarbon decay is detected by two 56 DVP photomultipliers in coincidence. A shielding iron-tunnel and a system of plastic scintillators with four anticoincidence photomultipliers are used for minimizing background.

Typical performance figures for a measurement time of 24 hours are:

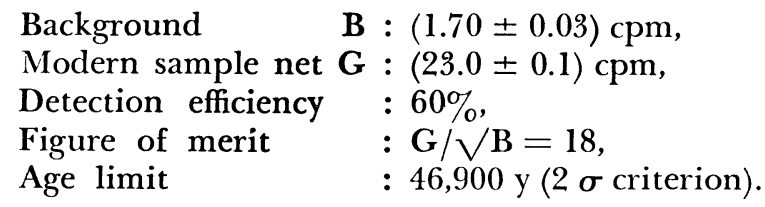

Dates are reported in conventional radiocarbon years, assuming year 1950 as reference standard and Libby's half-life of $5570 \pm 30$ years (Libby, 1955). Our modern standard has been obtained from the 1950 core of an Abies picea trunk. It has not been calibrated against National Bureau of Standard's oxalic acid. The counting rate is not corrected for isotopic fractionation, because a mass-spectrometer is not available at present.

\section{SAMPLE DESCRIPTIONS}

The results reported here are part of a study of the paleography of the lagoon of Venice. The list contains dates of different samples selected from the same core at different depths in the stratigraphic sequence, in order to verify the sedimentation rate. Also, some dates of samples from other cores are reported, which may give some information on local stratigraphic sequence.

* Istituto Nazionale di Fisica Nucleare, Sezione di Trieste, Facoltà di Ingegneria, Università degli Studi di Trieste 
In all cases, samples have been prepared from the most suitable materials, $i e$, wood and peat or, if these were not available, mollusk shells.

Laguna di Venezia

$$
\text { GEOLOGIC SAMPLES }
$$

Terre Perse series

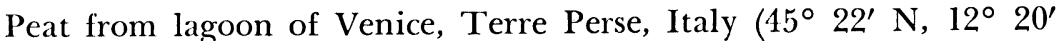
$56^{\prime \prime}$ E). Coll 1973 by P Da Roit, Lab Geol Appl CNR, Univ Padova, and subm by P Gatto, Ist Studio Dinamica Grandi Masse, CNR, Venice.

UD-3.

$21,000 \pm 800$

Peat from drilling 7 at depth $17.2 \mathrm{~m}$.

UD.4.

$$
23,000 \pm 1000
$$

Peat from drilling 7 at depth $25.60 \mathrm{~m}$.

UD-5.

$16,400 \pm 500$

Peat from drilling 7 at depth $14.85 \mathrm{~m}$.

\section{Ca' Bianca series}

Peat and shells from Lagoon of Venice, $\mathrm{Ca}^{\prime}$ Bianca $\left(45^{\circ} 23^{\prime} 33^{\prime \prime} \mathrm{N}\right.$, $12^{\circ} 21^{\prime} 18^{\prime \prime} \mathrm{E}$ ). Coll 1973 by P Da Roit and subm by P Gatto.

UD-6.

$28,000 \pm 1700$

Peat from drilling 8 at depth $29.6 \mathrm{~m}$.

UD-7.

$22,000 \pm 900$

Peat from drilling 8 at depth $25 \mathrm{~m}$.

UD-21.

$\mathbf{4 7 0 0} \pm 150$

Shells from drilling 8 at depth $9.6 \mathrm{~m}$.

\section{Malamocco series}

Peat and carbonate (mollusk shells) from lagoon of Venice, Malamocco $\left(45^{\circ} 21^{\prime} 53^{\prime \prime} \mathrm{N}, 12^{\circ} 20^{\prime} 14^{\prime \prime}\right)$. Coll 1974 by $\mathrm{P}$ Da Roit and subm by $\mathbf{P}$ Gatto.

UD-9.

$$
25,000 \pm 1500
$$

Peat from drilling 6 at depth $26 \mathrm{~m}$.

UD-14.

Peat from drilling 6 at depth $18.3 \mathrm{~m}$.

UD-20.

Carbonate (mollusk shells) from drilling 6 at depth $8.9 \mathrm{~m}$.

UD-23.

Carbonate (mollusk shells) from drilling 6 at depth $11.6 \mathrm{~m}$.

$$
21,000 \pm 1000
$$

$$
5300 \pm 200
$$




\section{$S$ Pietro in Volta series}

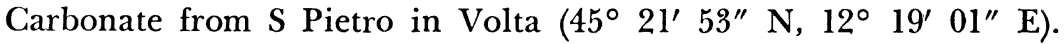
1976 by P Da Roit and subm by P Gatto.

UD-22.

Carbonate (mollusk shells) from drilling 1 at depth $11.6 \mathrm{~m}$.

\section{Pellestrina series}

Carbonate from Pellestrina $\left(45^{\circ} 15^{\prime} 58^{\prime \prime} \mathrm{N}, 12^{\circ} 18^{\prime} 04^{\prime \prime} \mathrm{E}\right)$. Coll 1976 by P Da Roit and subm by P Gatto.

UD-18.

$$
11,000 \pm 200
$$

Carbonate (mollusk shells) from drilling 4 at depth $17.35 \mathrm{~m}$.

\section{Alberoni series}

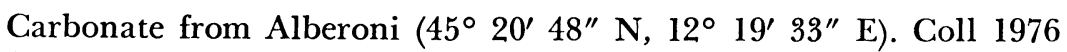
by P Da Roit and subm by P Gatto.

UD-19.

$4300 \pm 200$

Carbonate (mollusk shells) from drilling 5 at depth $6.9 \mathrm{~m}$.

\section{Forte di S Andrea series}

Peat from Forte di S Andrea $\left(45^{\circ} 26^{\prime} 01^{\prime \prime} \mathrm{N}, 12^{\circ} 22^{\prime} 53^{\prime \prime} \mathrm{E}\right)$. Coll 1974 by P Da Roit and subm by P Gatto.

\section{UD-15.}

Peat from drilling 9 at depth $27.9 \mathrm{~m}$.

\section{REFERENCES}

Barbina, Valerio, Calligaris, Franco, and Ciuti, Piero, 1979, An apparatus for betacounting used in a radiocarbon dating laboratory: Nucl Instruments and Methods, v 163, p $545-548$.

Belluomini, G, Delfino, A, Manfra, L, and Petrone, V, 1978, Benzene synthesis for radiocarbon dating and study of the catalyst used for acetylene trimerization: Internatl Jour Appl Radiation and Isotopes, v 29, p 453-459.

Calligaris, Franco and Ciuti, Piero, 1978, Principi generali e caratteristiche fisiche del servizio di radiodatazione con ${ }^{14} \mathrm{C}$ : Centro Ricerca Appl e Documentazione, Udine, Quad no. 7.

CRAD, 1977, Servizio di radiodatazione con ${ }^{14} \mathrm{C}$ : Bull no. 1.

Legers, C and Tamers, M A, 1963, The counting of naturally occurring radiocarbon in the form of benzene in a liquid scintillator counter: Internatl Jour Appl Radiation and Isotopes, v 14, p 65-70.

Libby, W F, 1955, Radiocarbon dating: Chemistry in Britain, v 5, p 548-552.

Noakes, J E, Kim, S H, and Akers, L K, 1967, Recent improvements in benzene chemistry for radiocarbon counting: Geochim et Cosmochim Acta, v 31, p 1094-1096. 